\title{
EVALUATION OF SIKORA INSTEAD OF SMP BUFFER TO ESTIMATE THE POTENTIAL ACIDITY OF BRAZILIAN SOILS ${ }^{(1)}$
}

\author{
Maria Alice Santanna ${ }^{(2)}$, João Kaminski ${ }^{(3)}$, Danilo dos \\ Santos Rheinheimer ${ }^{(4)}$, Jaderson dos Anjos Toledo ${ }^{(5)}$ \& \\ Carlos Alberto Casali (6)
}

\begin{abstract}
SUMMARY
Despite the efficiency of the Shoemaker, McLean, Pratt (SMP) buffer method in estimating soil acidity, the presence of $p$-nitrophenol and potassium chromate in the solution, both hazardous substances, has caused increasing environmental concerns. The purpose of this study was to test Sikora method (Sikora, 2006) as an alternative to the adapted SMP buffer method, generally used to estimate potential acidity of Southern Brazilian soils. For the test, 21 soils in the South and Cerrado regions of Brazil were sampled. (1) The potential acidity values of these soils range from 35.95 to $4.02 \mathrm{cmol}_{\mathrm{c}} \mathrm{kg}^{-1}$ of soil, reflecting a wide acidity variation. The Sikora buffer does not mimic the adapted SMP buffer used in Southern Brazil, since the former has a low ability to distinguish soils with different acidity from each other, probably due to the higher buffer capacity than of the adapted SMP solution.
\end{abstract}

Index terms: soil acidity, liming, hazardous chemicals.

\footnotetext{
(1) Received for publication in July 5, 2010 and approved in June 15, 2011.

(2) Associate professor at the Department of Physics of Federal University of Santa Maria (UFSM), CEP 97105-900, Santa Maria, RS, Brazil. E-mail: alice@smail.ufsm.br

(3) Collaborate professor of the Post-Graduate Program in Soil Science (PPGCS), UFSM. E-mail: jk@smail.ufsm.br

(4) Associate professor at the Department of of Soils, UFSM. E-mail: danilor@smail.ufsm.br

(5) Doctoral student, PPGCS, UFSM. E-mail: jaderdat@yahoo.com.br

(6) Doctoral student, PPGCS, UFSM. E-mail: betocasali@yahoo.com.br
} 


\title{
RESUMO: AVALIAÇÃO DO TAMPÃO SIKORA COMO ALTERNATIVA PARA O TAMPÃO SMP NA ESTIMATIVA DA ACIDEZ POTENCIAL DE SOLOS BRASILEIROS
}

\begin{abstract}
Apesar da eficiência do tampão SMP na estimativa da acidez do solo, atualmente vêm aumentando as preocupações ambientais devido à presença de p-nitrofenol e cromato de potássio. O objetivo deste trabalho foi testar o método proposto por Sikora (2006) como alternativa ao tampão SMP (Tedesco et al., 1995), que é utilizado para estimar a acidez potencial dos solos da Região Sul do Brasil. O teste foi feito com 21 solos, coletados na Região Sul e no Cerrado. Os valores de acidez potencial real desses solos variaram de 35,95 a 4,02 $\mathrm{cmol}_{c} \mathrm{~kg}^{-1}$ de solo, refletindo ampla variação de acidez. O tampão Sikora não mimetizou o tampão SMP adaptado utilizado na Região Sul do Brasil, já que o primeiro apresentou baixa capacidade de distinguir entre solos com acidez diferente em razão, provavelmente, da sua alta capacidadetampão, em comparação com a solução SMP adaptada.
\end{abstract}

Termos de indexação: acidez do solo, calagem, substâncias químicas perigosas.

\section{INTRODUCTION}

The SMP buffer, developed by Shoemaker et al. (1961), is one of most commonly used methods to esrtimate soil potential acidity in Brazil, due to its simplicity, efficiency and quickness. SMP solution contains four chemical substances that act as weak bases to buffer the $\mathrm{pH}$ (triethanolamine, $p$-nitrophenol, potassium chromate and calcium acetate), along with calcium chloride, to control the ionic strength. Around five decades ago, the SMP method was adapted to estimate potential acidity in the States of Rio Grande do Sul and Santa Catarina, in southern Brazil (CQFSRS/SC, 2004). The formulation of the adapted SMP buffer (Tedesco et al., 1995) differs slightly from the original SMP buffer proposed by Shoemaker et al. (1961), since the former contains half the amount of calcium acetate of the original solution. The procedure to determine the $\mathrm{pH}$-SMP is analogous to a singlepoint, potentiometric titrimetry, where the SMP solution acts as a base of known concentration and the soil as an acid. Thus, when the soil sample is added to the buffer solution, the $\mathrm{pH}$ in the soil suspension decreases due to the neutralization reaction between the soil potential acidity $(\mathrm{H}+\mathrm{Al})$ and buffer bases. The final $\mathrm{pH}$ value of the soil-waterbuffer suspension is called pH-SMP. However, for a quantitative estimate, the measured $\mathrm{pH}$-SMP must be calibrated against the real potential acidity of the soil (Kaminski et al., 2002). This method is used to estimate the lime requirement of acid soils as well as the potential acidity to calculate the cation exchange capacity at $\mathrm{pH}=7.0$ (Kaminski et al., 2007).

For very acid soils that contain high amounts of organic matter, the SMP solution is not an ideal method, since frequently the $\mathrm{pH}$-SMP values are lower than the calibrated limit of most mineral soils. This suggests that the buffer capacity of the SMP solution is insufficient to counterbalance the high acidity of these soils, which is due to the several acid functional groups of the organic matter. Another problem is the composition of the SMP solution, which contains two toxic substances: $p$-nitrophenol and potassium chromate, in which hexavalent chromium is present. Upon conclusion of a $\mathrm{pH}$ SMP analysis, these compounds remain in the suspension residues. In most soil laboratories in Brazil, these residues are not adequately treated; instead, they are usually disposed in the environment. Therefore, to avoid environmental damage caused by these hazardous chemicals, it would be better to replace these two substances in the SMP solution, if possible, maintaining their efficiency as buffer.

In the literature, solutions have been described with similar behavior to some of the most commonly used buffers, in which the toxic substances were substituted by species without health or environmental risks, based on the similar buffer capacity of substitute and substituted species (Huluka, 2005; Sikora, 2006; Sikora \& Moore, 2008; Wolf et al., 2008). In relation to the SMP buffer, Vaughan (2004) suggested that the compounds imidazole or ethylenediamine could replace $p$-nitrophenol, while nitric or succinic acids could substitute the chromate salt.

However, since the buffer $\mathrm{pH}$ values of SMP and these new buffers are not the same, a lime calibration study (or conversion to SMP buffer $\mathrm{pH}$ ) is required to establish lime recommendations. Sikora (2006) addressed this problem a little differently, proposing a solution that would mimic the SMP buffer behavior, without requiring a new lime calibration study for soils where this method is already used. This author chose imidazole $(\mathrm{pKa}=6.95)$ to replace $\mathrm{p}$-nitrophenol $(\mathrm{pKa}=6.85)$, due to the similarity of the $\mathrm{pKa}$ values. Based on the same criteria, 2-(N-morpholino) ethanesulfonic acid monohydrate (MES) $(\mathrm{pKa}=6.10)$ was selected to replace chromate $(\mathrm{pKa}=5.81)$. The functional acidic group for imidazole and MES is a 
heterocyclic $\mathrm{N}$ atom. MES is a zwitterion (from the German zwitter, meaning hybrid), because the molecule has a positive charge in the protonated $\mathrm{N}$ atom and a negative one in the sulfonic group. The linearity of response of the new buffer to soil acidity is ensured by the similarity between pKa values of the replacing substances and those of the hazardous chemicals to be substituted. Besides, both MES and imidazole are stable, relatively inexpensive, readily available on the market and neither of the substances is known as hazardous.

Sikora buffer was closely correlated with SMP values for USA soils and, therefore, highly efficient in estimating their soil lime requirement. However, the efficiency for Brazilian soils has not been evaluated so far. The purpose of this study was to test Sikora as an alternative to the SMP buffer for potential acidity determination in soils in the South and Cerrado region of Brazil.

\section{MATERIAL AND METHODS}

\section{Soils}

Twenty one soil samples were collected from the 0-20 cm layer in different physiographic regions of Brazil: eleven from lowlands and seven from highlands of the State of Rio Grande do Sul and three from the Cerrado region. All samples were taken from native areas that had never been limed. After collection, the sample were air-dried, sieved through $2 \mathrm{~mm}$ mesh, plant debris manually removed, and chemical and physical analysis applied. Each sample was dispersed in sodium hydroxide solution before determining the particle size distribution; sand was separated by sieving and silt and clay, by sedimentation (Embrapa, 1997). The organic matter content was determined by wet digestion in a digester heating block (Yeomans \& Bremner, 1988). Water $\mathrm{pH}$ and $\mathrm{SMP} \mathrm{pH}$ were measured by a $\mathrm{pH}$ meter equipped with a combined $\mathrm{pH}$ electrode, consisting of a glass electrode and a silver/silver chloride reference electrode. The exchangeable cations $\mathrm{Ca}^{2+}, \mathrm{Mg}^{2+}$ and $\mathrm{Al}^{3+}$ were extracted from the soil using a $1 \mathrm{~mol} \mathrm{~L}^{-1} \mathrm{KCl}$ solution. $\mathrm{Al}^{3+}$ was determined by titration with a $0.0125 \mathrm{~mol} \mathrm{~L}^{-1} \mathrm{NaOH}$ solution, while $\mathrm{Ca}^{2+}$ and $\mathrm{Mg}^{2+}$ were analyzed by atomic absorption spectroscopy (Embrapa, 1997). The results of physical and chemical analysis are given in table 1.

\section{Lime incubation study}

Soil samples $(1.00 \mathrm{~kg})$ in three replications were moistened to $90 \%$ of the field capacity and then treated with increasing doses of $\mathrm{CaCO}_{3}$, equivalent to 0, 50, $75,100,125,150 \%$ of the potential acidity estimated by the SMP method to a target $\mathrm{pH}$ of 6.5 , before being stored in plastic bags and incubated for 130 days. Weekly, the plastic bags were opened and the soil was revolved. After incubation, soils samples were airdried, ground, sieved through $2 \mathrm{~mm}$ mesh and subjected to $\mathrm{pH}$ analysis (in water and SMP solution). The $\mathrm{pH}$ achieved in water by the incubated soil samples were plotted as a function of the amount of $\mathrm{CaCO}_{3}$ added. From this data, the potential acidity (measured $\mathrm{H}+\mathrm{Al}$ ) at $\mathrm{pH} 7.0$ was estimated for each soil as the lime requirement to raise the soil $\mathrm{pH}$ to a target level of 7.0.

Table 1. General characteristics of unlimed soil

\begin{tabular}{|c|c|c|c|c|c|c|c|c|c|c|c|}
\hline \multirow[b]{2}{*}{ Soil } & \multirow{2}{*}{ Clay $^{(1)}$} & \multirow{2}{*}{ Sand $^{(1)}$} & \multirow{2}{*}{ Silt $^{(1)}$} & \multirow{2}{*}{$O \mathbf{M}^{(1)}$} & \multicolumn{3}{|c|}{ pH } & \multirow{2}{*}{$\mathrm{Ca}^{(2)}$} & \multirow{2}{*}{$\mathbf{M g}^{(2)}$} & \multirow{2}{*}{$\mathbf{A l}^{(2)}$} & \multirow{2}{*}{$\begin{array}{c}\mathrm{H}+\mathbf{A l} \\
\text { measured }^{(4)}\end{array}$} \\
\hline & & & & & $\mathrm{H}_{2} \mathrm{O}^{(2)}$ & $\operatorname{SMP}^{(2)}$ & Sikora $^{(3)}$ & & & & \\
\hline & & $\mathrm{g} \mathrm{kg}^{-}$ & & & & & & & $-\mathrm{cm}$ & $\mathrm{kg}^{-1}$ & \\
\hline \multirow{11}{*}{ Lowland } & 84 & 689 & 228 & 11 & 4.9 & 6.3 & 6.8 & 1.01 & 0.30 & 0.55 & 6.07 \\
\hline & 293 & 104 & 603 & 36 & 5.0 & 5.9 & 6.3 & 13.20 & 4.25 & 0.15 & 12.17 \\
\hline & 160 & 509 & 331 & 15 & 4.1 & 5.5 & 6.2 & 0.41 & 0.09 & 2.00 & 8.38 \\
\hline & 206 & 215 & 579 & 27 & 4.4 & 5.6 & 6.1 & 5.94 & 1.63 & 0.98 & 11.21 \\
\hline & 195 & 391 & 413 & 17 & 4.4 & 5.8 & 6.2 & 3.34 & 1.14 & 1.38 & 10.73 \\
\hline & 377 & 62 & 561 & 22 & 5.1 & 5.9 & 6.2 & 12.33 & 3.74 & 0.43 & 10.62 \\
\hline & 56 & 782 & 162 & 12 & 4.5 & 6.7 & 7.0 & 0.28 & 0.16 & 0.43 & 4.22 \\
\hline & 59 & 763 & 177 & 13 & 5.4 & 6.8 & 7.1 & 1.59 & 0.77 & 0.00 & 4.02 \\
\hline & 164 & 544 & 292 & 23 & 4.6 & 6.0 & 6.3 & 2.55 & 0.84 & 0.70 & 8.46 \\
\hline & 64 & 776 & 159 & 15 & 4.6 & 6.3 & 6.8 & 1.59 & 0.71 & 0.45 & 4.86 \\
\hline & 139 & 585 & 276 & 18 & 4.4 & 5.9 & 6.5 & 1.71 & 0.79 & 0.88 & 7.13 \\
\hline \multirow[t]{7}{*}{ Highland } & 375 & 242 & 383 & 57 & 4.1 & 4.9 & 5.9 & 3.98 & 1.33 & 1.75 & 18.00 \\
\hline & 479 & 175 & 346 & 63 & 4.0 & 4.5 & 5.1 & 2.30 & 1.07 & 3.90 & 28.20 \\
\hline & 497 & 161 & 343 & 82 & 4.4 & 4.3 & 4.9 & 1.49 & 0.83 & 4.65 & 35.95 \\
\hline & 531 & 111 & 359 & 52 & 4.1 & 4.7 & 5.3 & 2.41 & 1.43 & 2.75 & 24.89 \\
\hline & 480 & 172 & 348 & 42 & 4.3 & 4.7 & 5.3 & 1.93 & 1.01 & 3.55 & 19.68 \\
\hline & 544 & 135 & 321 & 58 & 4.0 & 4.5 & 5.1 & 2.55 & 1.69 & 4.03 & 29.64 \\
\hline & 497 & 147 & 356 & 63 & 4.3 & 4.7 & 5.2 & 2.84 & 1.71 & 2.93 & 25.86 \\
\hline \multirow[t]{3}{*}{ Cerrado } & 601 & 164 & 235 & 40 & 5.2 & 5.8 & 6.3 & 3.20 & 1.51 & 0.10 & 9.99 \\
\hline & 230 & 730 & 40 & 23 & 5.0 & 6.2 & 6.7 & 1.90 & 0.54 & 0.23 & 6.56 \\
\hline & 293 & 649 & 58 & 29 & 4.9 & 6.0 & 6.5 & 2.48 & 1.09 & 0.30 & 10.41 \\
\hline
\end{tabular}

(1) Embrapa (1997). ${ }^{(2)}$ Tedesco et al. (1995). ${ }^{(3)}$ Sikora (2006). ${ }^{(4)}$ Values of soil incubated with lime. 


\section{Buffer pH measurements}

The $\mathrm{pH}$ measurements were carried out with a $\mathrm{pH}$ meter equipped with a combined $\mathrm{pH}$ electrode. Before measurements, the $\mathrm{pH}$ meter was calibrated with two buffer solutions at $\mathrm{pH} 4.00$ and 7.00. All measurements were made at room temperature, between 21 and $27^{\circ} \mathrm{C}$.

The buffer developed by Sikora (2006) was prepared as follows: $\mathrm{KCl}, 74.55 \mathrm{~g} \mathrm{~mol}^{-1} 1.5 \mathrm{~mol} \mathrm{~L}^{-1}$; triethanolamine $\left[\mathrm{N}\left(\mathrm{CH}_{2} \mathrm{CH}_{2} \mathrm{OH}\right)_{3}, 149.19 \mathrm{~g} \mathrm{~mol}^{-1}\right] 52.2 \mathrm{mmol} \mathrm{L}^{-1}$; imidazole $\left(\mathrm{C}_{3} \mathrm{H}_{4} \mathrm{~N}_{2}, 68.08 \mathrm{~g} \mathrm{~mol}^{-1}\right) 10.3 \mathrm{mmol} \mathrm{L}^{-1}$; MES [2-(N-morpholino) ethanesulfonic acid hydrate] $\left(\mathrm{C}_{6} \mathrm{H}_{13} \mathrm{NO}_{4} \mathrm{~S} . \mathrm{H}_{2} \mathrm{O}, 213.25 \mathrm{~g} \mathrm{~mol}^{-1}\right) 23.6 \mathrm{mmol} \mathrm{L}^{-1}$ and glacial acetic acid $\left(\mathrm{CH}_{3} \mathrm{COOH}, 60.05 \mathrm{~g} \mathrm{~mol}^{-1}\right)$ $67.00 \mathrm{mmol} \mathrm{L}^{-1}$. The initial $\mathrm{pH}$ value of the buffer was adjusted to 7.5 by adding $\mathrm{NaOH} 40 \% \mathrm{w} / \mathrm{w}$. To determine the soil $\mathrm{pH}$ values in this buffer ( $\mathrm{pH}$-Sikora), a soil suspension was prepared at 2:1:1 (mL of Sikora buffer: $\mathrm{mL}$ of water : $\mathrm{cm}^{3}$ of soil); the buffer dilution factor was 2:3, maintaining the concentration of the original Sikora buffer components in the soil suspension (Table 2).

The SMP solution contained calcium chloride dihydrate $\left(\mathrm{CaCl}_{2} \cdot \mathrm{H}_{2} \mathrm{O}, 147.01 \mathrm{~g} \mathrm{~mol}^{-1}\right) 0.721 \mathrm{~mol} \mathrm{~L}^{-1}$; triethanolamine $\left[\mathrm{N}\left(\mathrm{CH}_{2} \mathrm{CH}_{2} \mathrm{OH}\right)_{3}, 149.19 \mathrm{~g} \mathrm{~mol}^{-1}\right]$ $37.5 \mathrm{mmol} \mathrm{L}-1 ; \rho$-nitrophenol $\left(\mathrm{O}_{2} \mathrm{NC}_{6} \mathrm{H}_{4} \mathrm{OH}\right.$, $\left.139.11 \mathrm{~g} \mathrm{~mol}^{-1}\right) 26.2 \mathrm{mmol} \mathrm{L}^{-1}$, potassium chromate $\left(\mathrm{K}_{2} \mathrm{CrO}_{4}, 194.19 \mathrm{~g} \mathrm{~mol}^{-1}\right) 30.9 \mathrm{mmol} \mathrm{L}^{-1}$, calcium acetate $\left[\mathrm{Ca}\left(\mathrm{CH}_{3} \mathrm{COO}\right)_{2}, 158.17 \mathrm{~g} \mathrm{~mol}^{-1}\right] 12.6 \mathrm{mmol} \mathrm{L}^{-1}$. To achieve the desired initial buffer $\mathrm{pH}$ of 7.5, drops of $50 \% \mathrm{HCl}(\mathrm{v} / \mathrm{v})$ or $40 \% \mathrm{NaOH}(\mathrm{w} / \mathrm{w})$ were added. The $\mathrm{pH}$-SMP value was measured in a 1:2:2 soil suspension (SMP buffer: water: soil); i.e, the buffer dilution factor in the soil suspension was 1:3. It is worth mentioning that the composition of the SMP buffer was specifically adapted for the use for soils of Rio Grande do Sul (Tedesco et al., 1995), resulting in a slightly different formulation from the original SMP solution proposed by Shoemaker et al. (1961), since the former contains half of the original amount of calcium acetate.

The $\mathrm{pH}$-SMP and $\mathrm{pH}$-Sikora were determined in the unlimed and limed soils (50\% of the potential acidity estimated by SMP method to attain $\mathrm{pH}$ 6.5). A slurry of $10 \mathrm{~cm}^{3}$ of soil and $10 \mathrm{~mL}$ of water were agitated with a glass rod and left to stand for $30 \mathrm{~min}$, before determining the $\mathrm{pH}$, i.e. the soil-water $\mathrm{pH}$. Then $5 \mathrm{~mL}$ of SMP buffer was added, the mixture stirred with a glass rod, left to stand for $20 \mathrm{~min}$ and then stirred again, before determining the new $\mathrm{pH}$ value (pH-SMP) (Tedesco et al., 1995). Measurements of Sikora buffer $\mathrm{pH}$ are performed similarly, except for the buffer: water: soil proportion, which was 2:1:1.

\section{Statistical analysis}

Linear regression was applied to data of $\mathrm{pH}$-Sikora versus $\mathrm{pH}$-SMP of soils with natural potential acidity and soils with potential acidity influenced by liming, separately, considering the SMP-pH as independent variable.

Exponential regression of potential acidity (estimated by wet incubation) was performed as a function of the soil buffer $\mathrm{pH}$ measured using SMPRS/SC buffer (or Sikora buffer) of the limed and unlimed soils.

\section{RESULTS AND DISCUSSION}

The values of potential acidity observed within the range of 35.95 to $4.02 \mathrm{cmol}_{\mathrm{c}} \mathrm{kg}^{-1}$ of soil reflected a wide acidity variation (Table 1 ). This can be attributed to the influence of the acidity factors present in these soils, such as variable contents of organic matter and exchangeable aluminum (Kaminski, 1974). The highest organic matter content $\left(82-11 \mathrm{~g} \mathrm{~kg}^{-1}\right)$ and the highest amplitude of variation were observed in the lowland soils of Rio Grande do Sul, where different kinds of soils are found. The organic matter content of the highland soils of Rio Grande do Sul is similar (all $\left.>42 \mathrm{~g} \mathrm{~kg}^{-1}\right)$. The variation in exchangeable $\mathrm{Al}^{3+}$ contents in the studied soils was wide $\left(0-5 \mathrm{cmol}_{\mathrm{c}} \mathrm{kg}^{-1}\right)$. The Cerrado soils contained low values of exchangeable $\mathrm{Al}^{3+}\left(\sim 0.2 \mathrm{cmol}_{\mathrm{c}} \mathrm{kg}^{-1}\right)$. The data (Table 1) indicate that the samples were taken from a representative group of soils with a broad range of physical and

Table 2. Comparison of concentrations used in the soil suspension of the original Sikora buffer components and Sikora buffer in this study

\begin{tabular}{|c|c|c|c|c|}
\hline \multirow{2}{*}{ Substance } & \multicolumn{2}{|c|}{ Sikora buffer (original) } & \multicolumn{2}{|c|}{ Sikora buffer (this work) } \\
\hline & $\mathrm{mmol} \mathrm{L}^{-1}$ & Suspension $^{(1)}\left(\mathrm{mmol} \mathrm{L}^{-1}\right)$ & $\operatorname{mmol~L}^{-1}$ & Suspension $^{(1)}\left(\mathrm{mmol} \mathrm{L}^{-1}\right)$ \\
\hline Triethanolamine & 69.60 & 34.80 & 52.20 & 34.80 \\
\hline Imidazole & 13.70 & 6.85 & 10.30 & 6.87 \\
\hline MES & 31.40 & 15.70 & 23.60 & 15.73 \\
\hline Glacial acetic acid & 89.30 & 44.60 & 67.00 & 44.66 \\
\hline Potassium chloride & 2000 & 1000 & 1500 & 1000 \\
\hline Pronortion & \multirow{3}{*}{\multicolumn{2}{|c|}{$\begin{array}{c}\text { buffer : water : soil } \\
10: 10: 10 \mathrm{~mL} \\
1 / 2\end{array}$}} & \multirow{3}{*}{\multicolumn{2}{|c|}{$\begin{array}{c}\text { buffer : water : soil } \\
20: 10: 10 \mathrm{~mL} \\
2 / 3\end{array}$}} \\
\hline Proportion & & & & \\
\hline Dilution factor & & & & \\
\hline
\end{tabular}

(1) Concentration in the soil suspension. 
chemical characteristics, mainly with a wide variation in soil acidity levels.

When the buffer solutions (SMP or Sikora) get in contact with a soil sample, a $\mathrm{pH}$ reduction is observed, which is related with the potential acidity content of the soil. The obtained values were within the ranges 4.3 to 6.8 for $\mathrm{pH}-\mathrm{SMP}$ and 4.9 to 7.1 for $\mathrm{pH}-$ Sikora (Table 1). A linear relation between $\mathrm{pH}$-Sikora and pH-SMP values of limed and unlimed soils was obtained (Figure 1a), with correlation factor of 0.99 , angular coefficient of 0.846 and linear coefficient of 1.350; in other words, the buffer capacity of Sikora was higher than that of the adjusted SMP solution used in this study. These results differ from those obtained with the Sikora buffer for several soils in the USA (Sikora, 2006). This author also obtained a straight line, but with an angular coefficient very close to 1.0 and linear coefficient around zero. However, it is worth mentioning that Sikora used the SMP buffer in its original composition, as described by Shoemaker et al. (1961). The SMP solution used in this study is slightly different, containing half of the calcium acetate amount of the original SMP buffer. Since the anion acetate is the base of acetic acid, its buffering action is higher for soils with $\mathrm{pH}$ values near 4.5 ( $\mathrm{pKa}$ of acetic acid with ionic strength of $0.5 \mathrm{~mol} \mathrm{~L}^{-1}$, Martell $\&$ Smith, 1977). Therefore, the lower amount of acetate in the SMP buffer used is responsible for the lower buffering capacity when in contact with more acid soils, and is the cause of the lower angular coefficient of the straight line, compared to the analogous result of Sikora (2006) for soils of USA. Figure 1a also shows that a linear relation between pH-SMP and pH-Sikora can be obtained based on only the original soils (not treated with calcium carbonate), where the correlation factor is 0.98 , angular coefficient 0.869 and linear coefficient 1.229. On the other hand, considering only the soils after correction of $50 \%$ of potential acidity (limed soils), another linear relation between $\mathrm{pH}$-SMP and $\mathrm{pH}$-Sikora was obtained, with a correlation factor of 0.99 , angular coefficient of 0.825 and linear coefficient of 1.465. However, in both cases the linear and the angular coefficients of these straight lines are far from 0.0 and 1.0, respectively, which would be expected if the Sikora buffer mimicked the SMP perfectly.

Figure $1 b$ presents the relation between the real potential acidity $(\mathrm{H}+\mathrm{Al})$ and the values of $\mathrm{pH}-\mathrm{SMP}$ and $\mathrm{pH}$-Sikora determined for these soils, showing that in both cases the real $\mathrm{H}+\mathrm{Al}$ decreases exponentially as a function of $\mathrm{pH}$, but the decrease curve is more accentuated for $\mathrm{pH}$-Sikora than for $\mathrm{pH}$ SMP. In this figure, for both SMP and Sikora buffers, the soil samples with lower real potential acidity (due to liming, mostly) correspond to points located close to each other in the narrow range of higher $\mathrm{pH}$ values. However, this effect was much more pronounced in the case of Sikora than the SMP buffer. This behavior in not desirable, since it will increase laboratorial errors in the routine soil acidity estimation performed with Sikora buffer, because a slight variation in the measured Sikora pH will correspond to a great variation in the estimated value of $\mathrm{H}+\mathrm{Al}$. Soils with $\mathrm{H}+\mathrm{Al}$ values $>12 \mathrm{cmol}_{\mathrm{c}} \mathrm{kg}^{-1}$ are particularly important, since the Sikora solution has a lower ability to distinguish these soils from each other. Therefore, a higher probability of laboratory error is expected in the estimate of potential acidity of the studied soils with the Sikora than the SMP buffer. To be able to replace the SMP method, a solution with the same

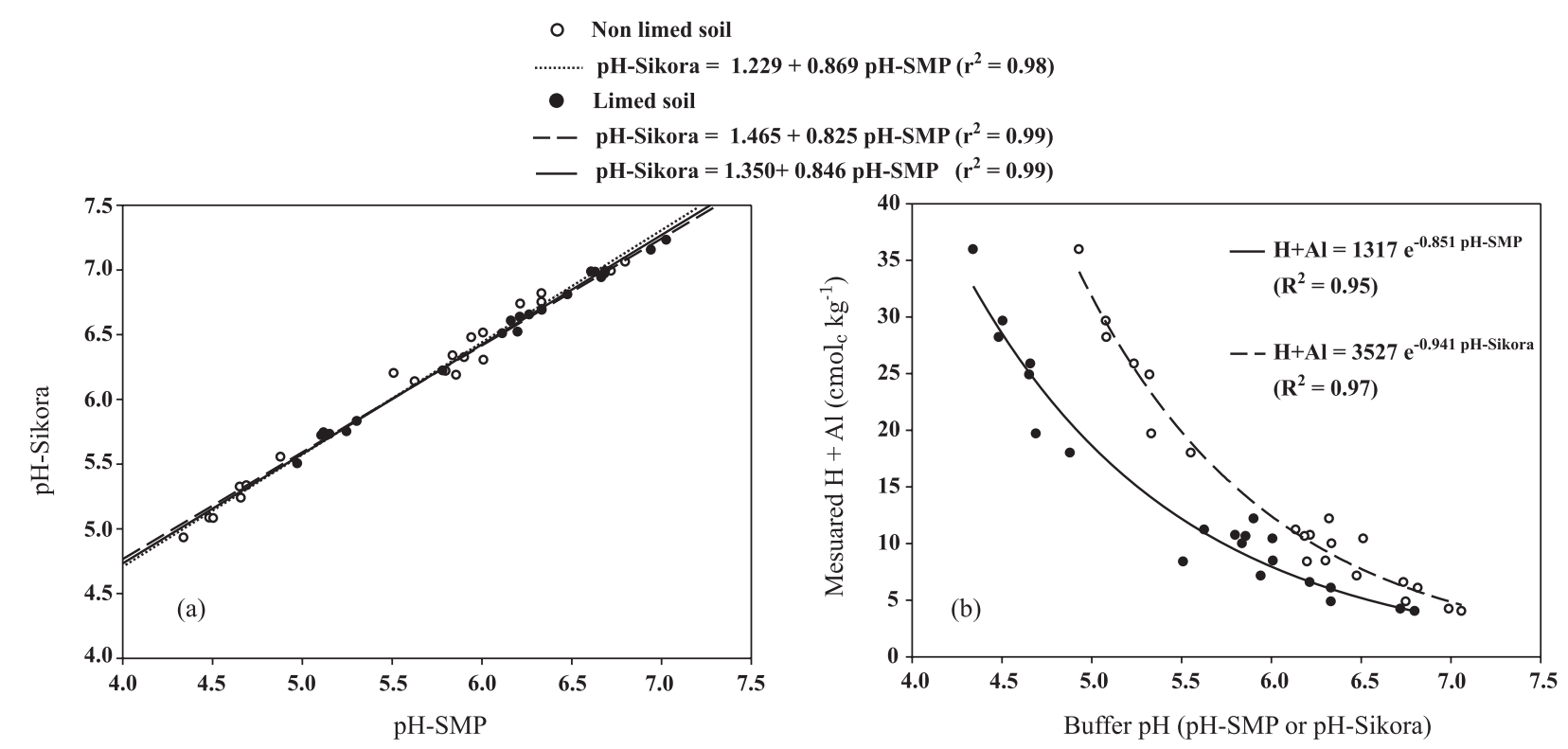

Figure 1. (a) Relationship between pH-SMP and pH-Sikora buffer in unlimed soils (dotted line), limed soils (dashed line) and total soils (continuous line) and (b) relationship between the buffer pH (pH-SMP, continuous line, and pH-Sikora, dashed line) and potential acidity of soil at pH 7.0. 
bases as Sikora buffer should be used in other concentrations to reduce the buffer capacity and consequently improve the ability to distinguish Brazilian soils with different values of real potential acidity.

\section{CONCLUSION}

The Sikora buffer does not reproduce the same soilbuffer $\mathrm{pH}$ as the SMP solution normally used to estimate the acidity of soils in Southern Brazil (Rio Grande do Sul and Santa Catarina states).

\section{ACKNOWLEDGEMENTS}

This study was financially supported by the Brazilian National Council for Scientific and Technological Development (CNPq).

\section{LITERATURE CITED}

COMISSÃO DE QUÍMICA E FERTILIDADE DO SOLO CQFSRS/SC. Manual de adubação e calagem para os Estados do Rio Grande do Sul e de Santa Catarina. 10.ed. Porto Alegre, Sociedade Brasileira de Ciência do Solo/ Núcleo Regional Sul/UFRGS, 2004. 400p.

EMPRESA BRASILEIRA DE PESQUISA AGROPECUÁRIA EMBRAPA. Centro Nacional de Pesquisa de Solos. Manual de métodos de análise de solo. 2.ed. Rio de Janeiro, 1997. $212 \mathrm{p}$

HULUKA, G. A modification to the Adams-Evans soil buffer determination solution. Comm. Soil Sci. Plant Anal., 36:2005-2014, 2005 .

KAMINSKI, J. Fatores de acidez e necessidade de calcário em solos do Rio Grande do Sul. Porto Alegre, Universidade Federal do Rio Grande do Sul, 1974. 96p. (Tese de Mestrado)
KAMINSKI, J.; GATIBONI, L.C.; RHEINHEIMER, D.S.; MARTINS, J.R.; SANTOS, E.J.S. \& TISSOT, C.A. Estimativa da acidez potencial em solos e sua implicação no cálculo da necessidade de calcário. R. Bras. Ci. Solo. 26:1108-1113, 2002.

KAMINSKI, J.; SILVA, L.S.; CERETTA, C.A. \& RENHEIMER, D.S. Acidez e calagem em solos do sul do Brasil: Aspectos históricos e perspectivas futuras. In: CERETTA, C.A.; SILVA, L.S. \& REICHERT, J.M., eds. Tópicos em ciência do solo. Viçosa, MG, Sociedade Brasileira de Ciência do Solo, 2007. v.5. p.307-332.

MARTELL, A.E. \& SIMITH, R.M. Critical stability constants. Other organic ligands. New York, Plenum Press, 1977. v.3.

SHOEMAKER, H.E.; MCLEAN, E.O. \& PRATT, P.F. Buffer methods for determining lime requeriment of soils with appreciable amounts of extractable aluminium. Soil Sci. Soc. Am. Proc., 25:274-277, 1961.

SIKORA, F.J. A buffer that mimics the SMP buffer for determining lime requirement of soil. Soil Sci. Soci. Am. J., 70:474-486, 2006.

SIKORA, F.J. \& MOORE, K.P. The Moore-Sikora buffer for lime requirement determinations. Soil Sci. Soci. Am. J., 72:1163-1173, 2008.

TEDESCO, M.J.; GIANELLO, C.; BISSANI, C.; BOHNEN, H. \& VOLKWEISS, S.J. Análise de solo, plantas e outros materiais. 2.ed. Porto Alegre, Universidade Federal do Rio Grande do Sul, 1995. 174p. (Boletim Técnico, 5)

VAUGHAN, B. Part 1: Review of buffer preparation and evaluation of commonly used buffers for determination of soil lime requirements. Lincoln, The Soil-Plant Analysis Newsletter, Summer 2004. Soil and Plant Analysis Council, 2004.

WOLF, A.M.; BEEGLE, D.B. \& HOSKINS, B. Comparison of Shoemaker-McLean-Pratt and modified Mehlich buffer tests for lime requirement on Pennsylvania soils. Comm. Soil Sci. Plant Anal., 39:1848-1857, 2008.

YEOMANS, J.C. \& BREMNER, J.M. A rapid and precise method for routine determination of organic carbon in soil. Comm. Soil Sci. Plant Anal., 19:1467-1476, 1998. 